\title{
Material transport and cycle in watersheds: toward the interdisciplinary collaboration between limnology and the other research disciplines
}

\author{
Mitsuyo Saito ${ }^{1}$ (D) Noboru Okuda $^{2,3} \cdot$ Shin-ichi Onodera ${ }^{4}$
}

Received: 12 June 2020 / Accepted: 15 June 2020 / Published online: 18 July 2020

(c) The Japanese Society of Limnology 2020

This special feature was originally planned based on the international joint session between JpGU (Japan Geoscience Union) and AGU (American Geophysical Union) in JpGU2018, named "Materials transport and nutrient cycles in watersheds; Human and climate impacts" which aimed to synthesize watershed sciences to understand dynamical processes of materials transport and nutrient cycles in watersheds from headwaters to coastal seas focusing on human and climate impacts.

"Watershed" is a hydrologic unit as a system of water and material (e.g., nutrient, sediment, and trace elements) cycles from headwaters to coastal seas. Numerous previous studies have shown that human activities alter the dynamics of nutrients, sediments, and pollutants, biogeochemical processes, and water resources on a global scale (Gruber and Galloway 2008; Rockström et al. 2009). However, de Vries et al. (2013) and Steffen et al. (2015) have pointed out the regional scale (e.g., watersheds) evaluation is more important for human impacts on biogeochemical cycle (e.g., nitrogen), because these impacts are spatially heterogeneous, also environmental problems such as eutrophication of water

Handling Editor: Ichiro Tayasu.

Mitsuyo Saito

misaito@okayama-u.ac.jp

1 Graduate School of Environmental and Life Science, Okayama University, 3-1-1, Tsushima-naka, Kitaku-Okayama, Okayama 700-8530, Japan

2 Research Institute for Humanity and Nature (RIHN), 457-4, Motoyama, Kamigamo, Kyoto, Kyoto 603-8047, Japan

3 Center for Ecological Research, Kyoto University, 2-509-3, Hirano, Otsu, Shiga 520-2113, Japan

4 Graduate School of Advanced Science and Engineering, Hiroshima University, 1-7-1, Kagamiyama, Higashi-Hiroshima 739-8521, Japan environments and biodiversity loss due to excess nitrogen input primarily occur at a regional level.

This feature aimed to integrate a variety of research disciplines including limnology, hydrology, biogeochemistry, agriculture, forestry, and microbiology. It also called for ideas on new methods to understand watershed processes, such as tracer and molecular technique, hydrological modeling, laboratory and field experiments, and so on. It will also challenge us to solve environmental problems on a watershed scale through the integration of such interdisciplinary research. Through the publication of this issue, we would like to facilitate interdisciplinary collaboration not only among members in the Japanese Society of Limnology but also with non-members who study watershed sciences.

Finally, four original articles and one review article were published in this feature. Some of the authors gave presentations at the international joint session in JpGU2018. The other articles focused on the phosphorus cycle were published in another special feature named "Phosphorus cycle in watersheds".

Key contents of the articles are summarized as follows:

1. Nguyen et al. (2020) Elemental concentration in a potentially protected forest catchment in Singapore (original article); The study was to understand and evaluate the catchment's soil and stream status through the assessment of elemental concentrations and their possible sources in a protected forest catchment in Singapore. Despite that the catchment is in natural status, localized anthropogenic disturbance to the catchment is obvious given the enrichment of various metals.

2. Matsuoka et al. (2020) Identifying microbial drivers promoting plant growth on soil amended with composted aquatic plant: insight into nutrient transfer from aquatic to terrestrial systems (original article); the present study is the first to demonstrate that the positive effects 
of composted aquatic plants on terrestrial plant growth are mediated by soil microbial processes. The results could provide basic insights into the transfer and cycling of nutrients from aquatic to terrestrial systems through human activities.

3. Harmon (2020) Carbon gas flux to and from inland waters: support for a global observation network (review article); this paper reviews carbon flux research in support of a proposed global carbon monitoring network to inform public policy. It begins with an overview of the physical-chemical processes and quantification tools for carbon gas flux and then highlights their application to streams, rivers, lakes, reservoirs, and estuaries.

4. Onishi et al. (2020) Developing a hydro-chemical model of Ise Bay watersheds and the evaluation of climate change impacts on discharge and nitrate-nitrogen loads (original article); this study developed a hydro-chemical model using the Soil and Water Assessment Tool (SWAT) and to evaluate the climate change impacts on discharge and nitrate-nitrogen loads from Ise Bay watersheds (the Kiso, Nagara, Ibi, and Shonai rivers).

5. Ridwansyah et al. (2020) The impact of land use and climate change on surface runoff and groundwater in Cimanuk watershed, Indonesia (Original article): This study was aimed to analyze the impact of land use and climate change on surface runoff and groundwater in Cimanuk watershed, Indonesia using an SWAT model. The modeled period showed that land use changes caused a general increase in runoff and a decline in base flow contribution to annual streamflow. The changes in climate between current climate and projected future climate (2075-2099) exhibit an increase in Qmax/Qmin ratio in certain years.

We do hope the papers presented in this special issue will help stimulate future research on watershed sciences, and we thank each of the handling editors (Dr. Thomas Harmon; University of California Merced and Dr. Jianyao Chen; Sun Yat-sen University, China) and reviewers whose generous insights and helpful suggestions improved these articles.

\section{References}

Gruber N, Galloway JN (2008) An Earth-system perspective of the global nitrogen cycle. Nature 451:293-296

Harmon TC (2020) Carbon gas flux to and from inland waters: support for a global observation network. Limnology 21:429-442. https:// doi.org/10.1007/s10201-020-00623-1

Matsuoka S, Kobayashi Y, Hobara S, Osono T (2020) Identifying microbial drivers promoting plant growth on soil amended with composted aquatic plant: insight into nutrient transfer from aquatic to terrestrial systems. Limnology 21:443-452. https://doi. org/10.1007/s10201-020-00613-3

Nguyen CTT, Kim DE, Liu J, Cai Y, Liong S-Y (2020) Elemental concentration in a potentially protected forest catchment in Singapore. Limnology 21:453-463. https://doi.org/10.1007/s1020 1-020-00620-4

Onishi T, Yoshino J, Hiramatsu K, Somura H (2020) Developing a hydro-chemical model of Ise Bay watersheds and the evaluation of climate change impacts on discharge and nitrate-nitrogen loads. Limnology 21:465-486. https://doi.org/10.1007/s1020 1-020-00622-2

Ridwansyah I, Yulianti M, Apip Onodera S, Shimizu Y, Wibowo H, Fakhrudin M (2020) The impact of land use and climate change on surface runoff and groundwater in Cimanuk watershed, Indonesia. Limnology 21:487-498. https://doi.org/10.1007/s1020 1-020-00629-9

Rockström J, Steffen W, Noone K, Persson Å, Chapin FS III, Lambin E, Lenton TM, Scheffer M, Folke C, Schellnhuber HJ, Nykvist B, De Wit CA, Hughes T, van der Leeuw S, Rodhe H, Sörlin S, Snyder PK, Costanza R, Svedin U, Falkenmark M, Karlberg L, Corell RW, Fabry VJ, Hansen J, Walker B, Liverman D, Richardson K, Crutzen P, Foley J (2009) Planetary boundaries: exploring the safe operating space for humanity. Ecol Soc 14(2):32

Steffen W, Richardson K, Rockström J, Cornell SE, Fetzer I, Bennett EM, Biggs R, Carpenter SR, de Vries W, de Wit CA, Folke C, Gerten D, Heinke J, Mace GM, Persson LM, Ramanathan V, Reyers B, Sörlin S (2015) Planetary boundaries: guiding human development on a changing planet. Science 347:1259855. https:// doi.org/10.1126/science.1259855

Vries W, Kros J, Kroeze C, Seitzinger SP (2013) Assessing planetary and regional nitrogen boundaries related to food security and adverse environmental impacts. Curr Opinion Environ Sust 5:392-402. https://doi.org/10.1016/j.cosust.2013.07.004

Publisher's Note Springer Nature remains neutral with regard to jurisdictional claims in published maps and institutional affiliations. 